\title{
Spindle and Kinetochore-Associated Protein 2
}

National Cancer Institute

\section{Source}

National Cancer Institute. Spindle and Kinetochore-Associated Protein 2. NCI Thesaurus. Code C118354.

Spindle and kinetochore-associated protein 2 (121 aa, 14 kDa) is encoded by the human SKA2 gene. This protein plays a role in both chromosome segregation and microtubule binding. 